\title{
The importance of p16 and CD117 expression in melanocytic lesions
}

\section{Melanositik lezyonlarda p16 ve CD117 ekspresyonunun önemi}

\author{
Sevil KARABAĞ $\breve{G}^{1 @(D)}$, Ayşegül İSAL ARSLAN ${ }^{1}(D)$ \\ ${ }^{1}$ Tekirdağ Namık Kemal University, Medical Faculty, Pathology Department, 59030, Tekirdağ-Turkey
}

Atıf gösterme/Cite this article as: Karabağ S, İsal Arslan A. The importance of P16 and CD117 expression in melanocytic lesions. ADYÜ Sağllk Bilimleri Derg. 2021;7(2):113-119. doi:10.30569.adiyamansaglik.890978

\begin{abstract}
Aim: The present study aims to determine the p16 and CD117 expression profiles of melanocytic lesions to investigate immune profiles that may facilitate differential diagnosis of melanoma from benign or potential precursor melanocytic lesions.

Materials and Methods: Immunohistochemistry for p16 and CD117 was applied in a total of 81 cases with melanocytic lesions.

Results: A significant loss of p16 expression was found in melanoma cases compared to benign and precursor melanocytic lesions $(p<0.05)$. Moreover, a significant loss of p16 expression was also noted in cases of dysplastic nevus compared to those with intradermal nevus $(p<0.01)$. While no CD117 expression was observed in intradermal nevi, highlevel expression was seen in cases with Spitz nevus, blue nevus, invasive melanoma and dysplastic nevus $(p<0.01)$.
\end{abstract}

Conclusion: We believe using p16 and CD117 together may provide an important marker combination to aid in distinguishing melanoma from benign lesions and benign lesions from potential precursor melanocytic lesions.

Keywords: Melanocytic tumors; Immunohistochemistry; P16; CD117.
Öz

Amaç: Bu çalışmada melanositik lezyonların p16 ve CD117 ekspresyon profillerini belirleyerek, melanomun diğer benign ya da potansiyel prekürsör melanositik lezyonlardan ayırıcı tanısını yapmayı kolaylaştıracak immün profillerini saptamayı amaçladik.

Gereç ve Yöntem: Seksen bir melanositik lezyon olgusuna immünohistokimya ile p16 ve CD117 uyguland1.

Bulgular: Melanom olgularında diğer benign ve prekürsör melanositik lezyonlara kıyasla anlamlı olarak p16 ekpresyon kayb1 mevcuttur $(p<0.05)$. Ayrica displastik nevüs olgularında da intradermal nevüs olgularına göre anlamlı olarak p16 ekspresyonunda kayıp mevcuttur $(p<0.01)$. CD117 ise intradermal nevüslerde eksprese olmaz iken, spitz nevüs, blue nevüs, invaziv melanom ve displastik nevüslerde ise yüksek oranda ekspresyon mevcuttur $(p<0.01)$.

Sonuç: p16 ve CD117 belirteçlerinin birlikte kullanıldığı zaman, melanomları benign lezyonlardan ve benign lezyonları potansiyel prekürsör melanositik lezyonlardan ayırımda önemli belirteçler olarak katkı sağlayacağını düşünmekteyiz.

Anahtar Kelimeler: Melanositik tümör; İmmünohistokimya; P16; CD117.

Yazışma Adresi/Address for Correspondence: Sevil KARABAĞ, Tekirdağ Namık Kemal University, Medical Faculty, Pathology Department, 59030, Tekirdağ-Turkey, E-mail: eesevil-krbg@ hotmail.com

Geliş Tarihi/Received:04.03.2021 Kabul Tarihi/Accepted:09.05.2021

Yayım Tarihi/Published online:30.08.2021

Bu eser, Creative Commons Atıf-GayriTicari 4.0 Uluslararası Lisansı ile lisanslanmıștır. Telif Hakkı @ 2021 Adıyaman Üniversitesi Rektörlüğü 


\section{Introduction}

Cutaneous melanocytic tumors constitute a broad spectrum of tumors with highly heterogeneous prognosis and morphological appearance. The distinction between precursor malignant lesions and benign nevus types proves to be challenging due to the heterogeneous morphology. ${ }^{1}$ Melanoma is a cutaneous neoplasm associated with high mortality. Although surgical resection may be curative in early stages, high rates of local recurrence and metastasis are observed despite chemotherapy and immunotherapy. ${ }^{2}$ Accurate recognition of primary melanoma is of critical importance for treatment management. Unfortunately, differential diagnosis is often challenging with the use of standard histological criteria and distinction of melanoma from chronically inflamed nevus, Spitz nevus and dysplastic/atypical nevus may even be impossible in some patients. . $^{3,4}$

Although genetic studies have led to the development of a modern morphogenetic classification, it is not deemed practical for routine use in everyday practice. Diagnostic molecular tests are either not used or only used in the most challenging and critical cases owing to the fact that these techniques require a molecular pathology lab and experienced pathologists to interpret the findings in addition to being costly tests with long turnaround time ${ }^{3}$. Convenient techniques such as immunohistochemistry (IHC) are widely used appropriate diagnostic tools in first-line setting. ${ }^{1}$ IHC is the most common adjunct test pathologists use to distinguish between benign and malignant melanocytic lesions. Although immune markers such as S100, HMB45, Melan-A, Sox-10 are broadly used in the differential diagnosis of melanocytic lesions, there is no single immune marker or panel to establish differential diagnosis with absolute precision. ${ }^{5}$

The tumor suppressor protein, p16, is the gene product of $C D K N 2 A$ and has been characterized as one of the proteins that regulate the G1/S checkpoint of the cell cycle and functions as an important effector. ${ }^{6}$ The role of p16 appears to be of great importance in cell aging, particularly in melanocytes, and aging is thought to be involved in tumor formation or progression of melanoma. ${ }^{7}$ In vitro cell culture studies further support this notion. Analyses of human melanocytes have revealed that cells depleted of p16 have enhanced proliferation and an extended replicative lifespan in the presence of replication-associated DNA damage. ${ }^{8}$ Studies that combined cell aging and its effects on melanoma have revealed presence of CDKN2A when analyzing the genetics of familial melanoma and found that a limited number of uncontrolled melanoma cases also had a p16 mutation. ${ }^{9}$ The observation of germline mutations in cases of melanoma has led to the application of p16 IHC marker in melanoma cases. ${ }^{3}$

C-KIT (CD117) is a transmembrane tyrosine kinase that plays a physiological role in the development of various cell types such as hematopoietic cells, breast epithelium, germ cells and melanocytes. ${ }^{10,11}$ Changes in CD117 expression are known to play a key role in tumor cell growth, proliferation and metastasis in several types of neoplasms including gastrointestinal stromal tumors (GIST), germ cell tumors and mastocytosis. Therefore, oncogenic mutations in KIT have become a focus of studies on melanoma and melanocyte transformation in recent years. ${ }^{12,13}$ C-KIT has an important role in the pathogenesis of melanoma, especially in acral and mucosal melanoma. ${ }^{14,15}$ Relevant studies have reported the frequency of C-KIT mutations as $1-7 \%$ in melanomas. ${ }^{16,17}$

The present study aims to determine the p16 and CD117 expression profiles in different melanocytic lesions classified as benign/precursor and malignant and identify immune profiles that may aid in the differential diagnosis of melanoma with poor prognosis and survival from benign or potential precursor melanocytic lesions.

\section{Materials and Methods}

\section{The type and sample of the research}

This retrospective study included a total of 81 melanocytic lesions diagnosed in 20122019, including 27 benign nevi, 12 blue nevi, five Spitz nevi, 17 dysplastic nevi and 20 cases of primary invasive malignant 
melanoma. While all malignant melanoma, spitz nevus and blue nevus cases from 7 years in our archive were included in the study, randomly selected cases of benign nevus and dysplastic nevus were included in the study. Since the number of cases of benign and dysplastic nevi in 7 years was large, the cases were randomly selected with the number of cases similar to the other cases. The patients' paraffin-embedded blocks were retrieved from the archive and eligible blocks of lesions were selected.

Sections of 4-micron thickness were obtained from 81 formalin-fixed, paraffinembedded tissues for IHC analysis and positive-charged microscope slides were used to avoid tissue shedding. The sections were allowed in an incubator at $60^{\circ} \mathrm{C}$ for an hour and deparaffinized with xylene for 15 minutes. The samples were hydrated through descending-grade series of alcohol and washed in distilled water. Samples were then introduced to a BenchMark XT device. Antibodies for p16 (ABM, 1:100) and CD117(Ventana, RTU) were applied and staining was performed. The samples stained in the automated staining device were covered using fluid-based covering material. Results were evaluated with an Olympus CX41 light microscope.

\section{Analysis of data}

For each case, both H\&E (hematoxylineosin) and IHC slides were analyzed by two pathologists concurrently. Only nuclear staining was accepted positive during the evaluation of p16 staining pattern. The p16 staining was scored as follows: 3 (>50\% positive cells), 2 (11-50\% positive cells), 1 (1-10\% positive cells), 0 ( $0 \%$ positive cells). ${ }^{1}$

CD117 immunostaining was graded with a semiquantitative approach as follows: 0 (no staining), $1+(1-10 \%$ staining $), 2+(11-29 \%$ staining $), 3+(30-50 \%$ staining $)$ or $4+(>50 \%$ staining). ${ }^{11}$ CD117 staining pattern was assessed both in the cytoplasm and the cytoplasmic membrane.

\section{Statistical method}

Patient demographics and data were analyzed using the SPSS 24 program.
Variables were expressed as frequency, percentage, mean (arithmetic mean, median), standard deviation (min-max), tables and graphs. ANOVA was used to compare the variables between diagnostic groups. $p<0.05$ was considered statistically significant.

\section{Ethics committee approval}

The study was approved by the NonInterventional Clinical Trials Ethics Committee (Decision no 2020.116.05.17). The research has been prepared in accordance with the Declaration of Helsinki Principles.

\section{Results}

Mean age of the 81 patients was 40.4 years (min: 8, max: 93). There were a total of 81 patients including 27 with intradermal nevus $(33.3 \%), 20$ with primary malignant melanoma (24.7\%), 17 with dysplastic nevus (21\%), 12 with blue nevus (14.8\%) and five with Spitz nevus (6.2\%). Three of the displastic nevi cases had mild, three of had severe atypia and others had moderate atypia. Although dysplastic nevi were divided into groups as mild, moderate and severe, all of them were considered as a single group when evaluating the staining results. The difference in p16 and CD117 staining between all melanocytic groups was statistically significant $(p<0.01)$. A post-hoc test comparing the groups in pairs revealed a significant loss of p16 expression in melanoma cases compared to benign and precursor melanocytic lesions. In addition, a significant loss of p16 expression was also noted in cases of dysplastic nevus compared to those with intradermal nevus. A dysplastic nevus case with complete p16 loss included severe dysplasia. P-values of the differences in p16 and CD117 expression across diagnoses are shown in Table 1 . The p16 and CD117 IHC staining of the cases are presented in Figure 1.

While a high level of p16 expression was observed in intradermal nevi, Spitz nevi and blue nevi, the expression was significantly reduced in dysplastic nevi, which represent melanocytic lesions with low risk of progression, and almost complete loss of staining was detected in invasive melanoma. 
Table 2 presents the p16 staining pattern of

the cases.

Table 1. P-values of the differences in p16 and CD117 expression across diagnoses.

\begin{tabular}{llccccc}
\hline Diagnosis & & $\begin{array}{l}\text { Malignant } \\
\text { melanoma }\end{array}$ & $\begin{array}{l}\text { Spitz } \\
\text { nevus }\end{array}$ & $\begin{array}{l}\text { Dysplastic } \\
\text { nevus }\end{array}$ & $\begin{array}{l}\text { Intradermal } \\
\text { nevus }\end{array}$ & Blue nevus \\
\hline Malignant melanoma & p16 & $\mathrm{X}$ & $\mathbf{0 . 0 1}$ & $\mathbf{0 . 0 4 9}$ & $\mathbf{0 . 0 1}$ & $\mathbf{0 . 0 1}$ \\
& $\mathrm{CD} 117$ & $\mathrm{X}$ & 0.73 & 1 & $\mathbf{0 . 0 1}$ & 0.55 \\
Spitz nevus & p16 & $\mathbf{0 . 0 1}$ & $\mathrm{X}$ & 0.12 & 0.99 & 0.77 \\
& $\mathrm{CD} 117$ & 0.73 & $\mathrm{X}$ & 0.75 & $\mathbf{0 . 0 7}$ & 1 \\
Dysplastic nevus & p16 & $\mathbf{0 . 0 4 9}$ & 0.12 & $\mathrm{X}$ & $\mathbf{0 . 0 1}$ & 0.48 \\
& $\mathrm{CD} 117$ & 1 & 0.75 & $\mathrm{X}$ & $\mathbf{0 . 0 1}$ & 0.6 \\
Intradermal nevus & p16 & $\mathbf{0 . 0 1}$ & 0.99 & 0.01 & $\mathrm{X}$ & 0.47 \\
& $\mathrm{CD} 117$ & $\mathbf{0 . 0 1}$ & $\mathbf{0 . 0 7}$ & $\mathbf{0 . 0 1}$ & $\mathrm{X}$ & $\mathbf{0 . 0 0 2}$ \\
Blue nevus & $\mathrm{p} 16$ & $\mathbf{0 . 0 1}$ & 0.77 & 0.48 & 0.47 & $\mathrm{X}$ \\
& $\mathrm{CD} 117$ & 0.55 & 1 & 0.6 & $\mathbf{0 . 0 0 2}$ & $\mathrm{X}$ \\
\hline
\end{tabular}

*Measurements that are statistically significant $(\mathrm{p}$ value $<0.05)$ are indicated in bold. ANOVA was used to compare the variables between diagnostic groups.

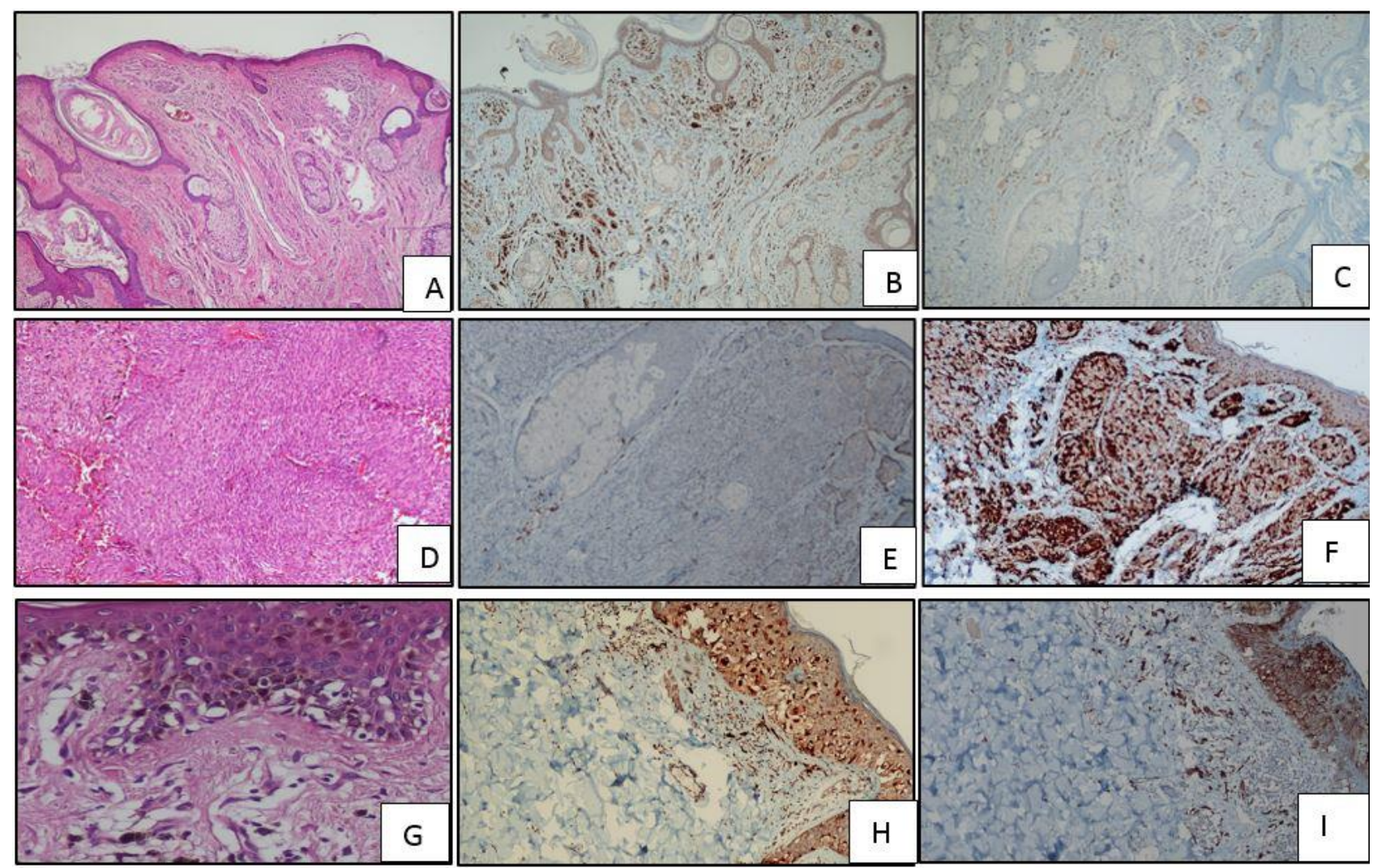

Figure 1. The p16 and CD117 IHC staining of the cases A) Nevus H\&E x100, B) Nevus p16x100, C) Nevus CD117x100 D) Malignant Melanoma H\&E x100, E) Malignant Melanoma p16 x100, F) Malignant Melanoma CD117x100 G) Displastic nevus H\&E x100, H) Displastic nevus p16x100, I) Displastic nevus CD117 x100

Table 2. p16 immunohistochemical staining pattern of all lesions.

\begin{tabular}{|c|c|c|c|c|c|c|}
\hline Diagnosis & $\begin{array}{c}\mathrm{p} 16 \\
\text { mean value }\end{array}$ & Score 0 & Score 1 & Score 2 & Score 3 & Total \\
\hline Malignant melanoma & $1.25 \pm 0.26$ & 8 & 1 & 9 & 2 & 20 \\
\hline Spitz nevus & $3 \pm 0$ & 0 & 0 & 0 & 5 & 5 \\
\hline Dysplastic nevus & $2 \pm 0.86$ & 1 & 3 & 8 & 5 & 17 \\
\hline Intradermal nevus & $2.85 \pm 0.08$ & 0 & 1 & 2 & 24 & 27 \\
\hline Blue nevus & $2.5 \pm 0.9$ & 0 & 3 & 0 & 9 & 12 \\
\hline
\end{tabular}

ANOVA was used to compare the variables between diagnostic groups

No CD117 expression was detected in intradermal nevi whereas significantly increased expression was observed in Spitz nevi as well as blue nevi. A high level of expression was seen in invasive primary melanoma and in dysplastic nevi. Table 3 presents the CD117 staining pattern of the cases. 
Table 3. CD117 immunohistochemical staining pattern of all lesions

\begin{tabular}{lccccccc}
\hline Diagnosis & CD117 & Score 0 & Score 1 & Score 2 & Score 3 & Score 4 & Total \\
Mean value & & & & & & & 6 \\
Malignant melanoma & $2.25 \pm 0.3$ & 2 & 4 & 7 & 1 & 20 & 5 \\
Spitz nevus & $1.6 \pm 0.5$ & 1 & 1 & 2 & 1 & 0 & 3 \\
Dysplastic nevus & $2.24 \pm 0.3$ & 0 & 7 & 2 & 5 & 0 & 27 \\
Intradermal nevus & $0.26 \pm 0.1$ & 21 & 5 & 1 & 0 & 1 & 12 \\
Blue nevus & $1.67 \pm 0.3$ & 1 & 5 & 4 & 1 & 1 & \\
\hline
\end{tabular}

ANOVA was used to compare the variables between diagnostic groups

\section{Discussion}

Our study supports that using p16 and CD117 together may provide an important marker combination to aid in distinguishing melanoma from benign lesions and benign lesions from potential precursor melanocytic lesions. In particular, p16 will be useful in differentiating malignant melanoma with dysplastic nevus containing severe atypia and CD117 in separating mild and moderate dysplasia nevus from benign nevi. A portion of melanocytic tumors require adjunct tools for pathologists to determine their malignancy potential due to the diagnostic difficulties encountered with these tumors. Although immune markers such as S100, Ki67, HMB45, Melan-A are Sox10 are commonly used in routine practice, these may fall short to establish the diagnosis and finalize differential diagnosis of melanoma ${ }^{5}$. After the KIT mutation was first described in melanoma, further mutations have been detected in exon 11, 13 and 17 of KIT in cutaneous melanomas. ${ }^{12}$ Mutations in exon 11 and $K 642 E$ point mutations of exon 13 are known to be the most important subsites of genetic alteration. ${ }^{18-20}$ Furthermore, KIT gene amplification has been detected in approximately $30 \%$ of melanoma cases bearing a KIT mutation. ${ }^{18,19}$ Using IHC, Torres-Cabala et al. demonstrated a significant relationship between the percentage of CD117-positive cells and KIT mutation status in melanoma. ${ }^{21}$ There are also studies in the literature that have shown CKIT expression in $31 \%$ of melanomas without detectable KIT mutation or amplification. ${ }^{22}$ Although reported rates may vary based on the subtype of melanoma, IHC results show CD117 expression in approximately $53.7 \%$ of primary cutaneous melanomas and in more than $80 \%$ of metastatic melanomas. ${ }^{22,23}$
Pilloni et al. applied IHC for CD117 in 60 melanocytic lesions and reported that the CD117 expression in melanocytes located in dermis may aid the differential diagnosis between superficial invasive melanoma and compound nevus or intradermal nevus. ${ }^{24}$ They suggested that CD117 may offer a useful diagnostic tool to distinguish benign compound nevi from malignant melanocytic lesions with dermis invasion and metastatic melanoma from primary melanoma. ${ }^{24}$

The present study showed that the CD117 IHC marker is not expressed in cases of intradermal nevus while near-complete expression is observed in cases of Spitz nevus and blue nevus, invasive melanoma and dysplastic nevi. Our results support that the CD117 IHC marker may be used as a marker for the differential diagnosis of invasive melanoma, especially in distinguishing them from compound nevi with dermal component. The finding that there was no CD117 staining greater than $30 \%$ in any case of intradermal nevus indicates that this marker is considerably successful in distinguishing these nevi from other lesions based on the diffuse staining. Furthermore, we observed that it may be a valuable marker also in distinguishing cases of intradermal nevus from rare blue nevi and Spitz nevi as well as dysplastic nevi, which represent precursor melanocytic lesions.

KIT mutations are seen in about $70-80 \%$ of GIST cases where this mutation plays a key role in treatment. The high rates of response treatment in GIST have led to studies with imatinib and similar therapeutics in patients with melanoma bearing KIT mutations, and screening for KIT mutations may offer novel treatment options for melanoma patients with poor prognosis. ${ }^{25}$ In the present study, CD117 expression score was $1+$ in four out of the 20 cases with primary invasive cutaneous 
melanoma, 2+ in seven, $3+$ in one and $4+$ in six. The CD117 expression we observed in cases of invasive melanoma suggests that it may be relevant to investigate potential treatment with tyrosine kinase inhibitors in these tumors.

Upon detection of germline $C D K N 2 A$ in cases of melanoma, studies on p16 IHC to distinguish benign melanocytic lesions, particularly from sporadic melanoma have demonstrated loss of p16 expression in melanomas. ${ }^{26}$ Subsequent studies revealed that p16 mutation rate is lower also in atypical/dysplastic nevi compared to that in melanoma cases. ${ }^{9}$ Studies suggest that p16 IHC may be used to distinguish melanoma from benign nevi, especially in the case that nuclear staining is taken into account. ${ }^{3,14}$

Koh and Cassarino reviewed all studies on p16 IHC in melanocytic lesions in the literature and published the pooled results of these studies. ${ }^{3}$ They reported the rate of p16 IHC staining as $61-100 \%$ in benign nevi and $12-93 \%$ in primary cutaneous invasive melanoma, highlighting the broad range of findings ${ }^{3}$. While some of the studies support the diagnostic use of p16 IHC to distinguish nevi from primary invasive melanoma, others report a lack of significant difference in staining pattern between these entities. ${ }^{3,27-30}$ However, the shared results of studies analyzing nodal metastases recommend using p16 IHC to distinguish nodal nevi from nodal metastatic melanoma. , $^{3,31,32}$

Studies on atypical nevi support that including p16 in the immune panel is useful in terms of distinguishing mild to moderate atypical cellular blue nevi from severe atypical blue nevi and melanomas. In this study dysplastic nevi were evaluated as a single group, while staining results were evaluated because our case numbers were small. On the other hand, they revealed loss of p16 in severe atypical cases similar to the cases of melanoma. Re-analysis of study results based on p16 staining pattern demonstrated p16 staining in $89-100 \%$ of benign nevi versus $50-68 \%$ in primary invasive melanoma when only nuclear staining was recognized as positive. According to this review that included several studies, the diagnostic value of p16 appears limited in melanocytic lesions; however, it supports the use of p16 IHC in the immune panel to distinguish benign nevi and dysplastic lesions from melanoma in the event that only nuclear staining is taken into account. $^{3}$

We considered only nuclear staining in our evaluation. High-level p16 expression was present in all benign lesions included in our study. We observed a heterogeneous staining pattern in dysplastic nevi. Our observations reflect that p16 is a useful marker to distinguish invasive melanoma from benign nevi when the nuclear and strong diffuse staining rates over $50 \%$ are considered for evaluation. We did not detect total loss in any of the cases with intradermal nevus, Spitz nevus or blue nevus. Therefore, one may conclude that loss of p16 is considerably specific for melanoma with dermal dominance, although with a lower rate of sensitivity.

While organizing our study, we prepared the case groups homogeneously, but the limitation of our study is that the only malignant group was invasive melanoma and the other groups were benign.

\section{Conclusions}

In conclusion, we believe adding p16 and CD117 IHC analyses to other routine markers in the immune panel for melanocytic lesions may allow a more successful approach in diagnosis compared to the current situation. In this regard, attention must be paid to the multiple-pattern staining features of p16 and nuclear staining should be considered for evaluation. In the present study, the p16 score was 0 in eight out of the 20 melanoma cases, $1+$ in one, $2+$ in nine and $3+$ only in 2 cases. Since total loss of p16 is observed only in melanoma, p16 IHC may be useful in the differential diagnosis of melanocytic lesions with dermal component. Furthermore, we believe the CD117 expression results of our study may light the way for future studies with tyrosine kinase inhibitors in malignant melanoma.

\section{Ethics Committee Approval}


The study was approved by the NonInterventional Clinical Trials Ethics Committee (Decision no 2020.116.05.17). The research has been prepared in accordance with the Declaration of Helsinki Principles.

\section{Author Contributions}

Idea, design, collection of resources, analysis and interpretation of results and literature, written and critical: SK, AİA.

\section{Conflict of Interest}

There is no conflict of interest among the authors.

\section{Financial Disclosure}

There is no financial disclosure.

\section{Statements}

These research results have not previously been presented.

\section{Peer-review}

Externally peer-reviewed.

\section{References}

1. Fouchardiere A, Caillot $\mathrm{C}$, Jacquemus $\mathrm{J}$, et al. $\beta$-Catenin nuclear expression discriminates deep penetrating nevi from other cutaneous melanocytic tumors. Virchows Archiv 2019; 474:539-550

2. Whittaker S. Adjuvant diagnosis of malignant melanoma. Clin Exp Dermatol. 2000; 25(6):497-502.

3. Koh SS, Cassarino DS. Immunohistochemical Expression of p16 in Melanocytic Lesions An Updated Review and Metaanalysis. Arch Pathol Lab Med 2018; 142, July

4. Troxel DB. Medicolegal aspects of error in pathology. Arch Pathol Lab Med. 2006;130(5):617-619

5. Ferringer T. Immunohistochemistry in Dermatopathology. Arch Pathol Lab Med 2015; Vol 139, January

6. Chandler H, Peters G. Stressing the cell cycle in senescence and aging. Curr Opin Cell Biol. 2013;25(6):765-771.

7. Ha L, Merlino G, Sviderskaya EV. Melanomagenesis: overcoming the barrier of melanocyte senescence. Cell Cycle. 2008;7(13):1944-1948.

8. Fung C, Pupo GM, Scolyer RA. P16 (INK)(4a) deficiency promotes DNA hyper-replication and genetic instability in melanocytes. Pigment Cell Melanoma Res. 2014;26(2):236246.

9. Hussussian CJ, Struewing JP, Goldstein AM, et al. Germline p16 mutations in familial melanoma. Nat Genet. 1994; 8(1):1521

10. Charpin C, Giusiano S, Charfi S, et al. Quantitative immunohistochemical expression of $\mathrm{c}$ Kit in breast carcinomas is predictive of patients' outcome. Br J Cancer. 2009;101:4854.

11. Lin YC, Chang YM, Ho JY, et al. C-kit Expression of Melanocytic Neoplasm and Association With Clinicopathological Parameters and Anatomic Locations in Chinese People. Am J Dermatopathol 2013;35:569-575

12. Went PT, Dirnhofer S, Bundi M, et al. Prevalence of KIT expression in human tumors. J Clin Oncol 2004; 22: 45144522.

13. Willmore-Payne C, Layfield LJ, Holden JA. C-KIT mutation analysis for diagnosis of gastrointestinal stromal tumors in fine needle aspiration specimens. Cancer 2005; 105: 165-170.
14. Koh SS, Roehmholdt BF, Cassarino DS Immunohistochemistry of p16 in nevi of pregnancy and nevoid melanomas. J Cutan Pathol. 2018; 45:891-896.

15. Liu HG, Kong MX, Yao Q, et al. Expression of Sox10 and c-kit in Sinonasal Mucosal Melanomas Arising in the Chinese Population. Head and Neck Pathol 2012; 6:401-408.

16. Elder DE, Massi D, Scolyer R, Willemze R. WHO classification of skin tumours. 4th ed. IARC Press, Lyon; 2018

17. Costa S, Byrne M, Pissaloux D, et al. Melanomas associated with blue nevi or mimicking cellular blue nevi: clinical, pathologic, and molecular study of 11 cases displaying a high frequency of GNA11 mutations, BAP1 expression loss, and a predilection for the scalp. Am J Surg Pathol 2016; 40:368-377.

18. Antonescu CR, Busam KJ, Francone TD, et al. L567P KIT mutation in anal melanomas correlates with KIT protein expression and is sensitive to specific kinase inhibition. Int $J$ Cancer. 2007;121:257-64.

19. Beadling C, Jacobson-Dunlop E, Hodi FS, et al. KIT gene mutations and copy number in melanoma subtypes. Clin Cancer Res. 2008;14:6821-8.

20. Satzger I, Schaefer T, Kuettler U, et al. Analysis of c-KIT expression and KIT gene mutation in human mucosal melanomas. Br J Cancer. 2008;99:2065-9.

21. Torres-Cabala CA, Wang WL, Trent J, et al. Correlation between KIT expression and KIT mutation in melanoma: a study of 173 cases with emphasis on the acrallentiginous/mucosal type. Mod Pathol. 2009;22:1446-56.

22. Curtin JA, Busam K, Pinkel D, Bastian BC. Somatic activation of KIT in distinct subtypes of melanoma. J Clin Oncol. 2006;24:4340-6

23. Alexis BJ, Martinez AE, Lutzky J. An immunohistochemical evaluation of c-kit (CD117) expression in malignant melanoma, and results of imatinib mesylate (Gleevec) therapy in three patients. Melanoma Res. 2005;15:283-5.

24. Pilloni L, Bianco P, Difelice E, et al. The usefulness of c-Kit in the immunohistochemical assessment of melanocytic lesions. European Journal of Histochemistry 2011; 55: 20.

25. Meng D, Carvajal RD. KIT as an Oncogenic Driver in Melanoma: An Update on Clinical Development. American Journal of Clinical Dermatology 2019; 20:315-323.

26. Sa BC, Fugimori ML, Ribeiro KC, et al. Proteins involved in $\mathrm{pRb}$ and $\mathrm{p} 53$ pathways are differentially expressed in thin and thick superficial spreading melanomas. Melanoma Res. 2009; 19(3):135-141.

27. Demirkan NC, Kesen Z, Akdag B, Delmas V. The effect of the sun on expression of beta-catenin, p16 and cyclin d1 proteins in melanocytic lesions. Clin Exp Dermatol. 2007; 32(6):733-739.

28. Zoroquiain P, Fernandes BF, Gonzalez S, Novais GN, Schalper $\mathrm{KA}$, Burnier MN. p16ink4a expression in benign and malignant melanocytic conjunctival lesions. Int J Surg Pathol. 2012; 20(3):240-245

29. Reed JA, Loganzo F, Shea CR, et al. Loss of expression of the p16/cyclindependent kinase inhibitor 2 tumor suppressor gene in melanocytic lesions correlates with invasive stage of tumor progression. Cancer Res. 1995; 55(13):2713-2718.

30. Tran SL, Haferkamp S, Scurr LL, et al. Absence of distinguishing senescence traits in human melanocytic nevi. $J$ Invest Dermatol. 2012; 132(9):2226-2234.

31. Mihic-Probst D, Saremaslani P, Komminoth P, Heitz PU. Immunostaining for the tumour suppressor gene p16 product is a useful marker to differentiate melanoma metastasis from lymph-node nevus. Virchows Arch. 2003;443(6):745-751.

32. Piana S, Tagliavini E, Ragazzi $M$, et al. Lymph node melanocytic nevi: pathogenesis and differential diagnoses, with special reference to p16 reactivity. Pathol Res Pract. 2015;211(5):381-388. 